\title{
EDITORIAL COMMENTARY
}

The Faculty of Social and Legal Sciences wishes to continue advancing in the interdisciplinary exercise of the social sciences which will permit the construction of a reflective, critical community for the production of socio-cultural and political knowledge, and in particular will lead to progress in interdisciplinary reflectionaction, cultivated in contextualized social sciences, in close, permanent dialogue with regional, national and international problems, offering alternatives and proposals based on disciplinary, professional and methodological specificities.

In this second number of 2008, the Culture-Man-Society Review of the Faculty of Social and Legal Sciences offers us three important matters for the development of the social sciences: one topic concerns the epistemology of social science, a second is about identity construction among the Mapuche who live in what is now Chilean and Argentinean territory, and the third phenomenological subject has to do with the values of love and justice.

On the first topic, the work of Dr Jorge Brower Beltramin entitled "Contributions of Structuralism to the design of a Communication Semiotic" develops reflection on certain key contributions produced by structuralism in areas such as linguistics, anthropology and mathematics, among others, for the production of analytical apparatus in the discipline of semiotics. Meanwhile Dr. Cristián Parker G., in his article: "The two cultures: Natural and Human Sciences in the 21st century", explains the conceptions of Chilean university students with respect to their representation and valuation of the sciences, technology and ethics, and in particular the traditional distinction between the logical-experimental sciences and the arts-humanities.

In the second topic, addressing the reconstruction of identity from the tales found currently in indigenous communities, professor Ramón Curivil Paillavil has developed a work entitled "Mapuche Culture: an ancient ideal of the person for a new history", in which he systematizes information on the idea of man or idea of person, modes of being, living and coexisting in the world and with the world. Mgr. Graciana Pérez Zavala, in her article "Mapuche and Ranquel peoples in Argentina: tales of their past and present", presents the reconstruction of tales of the past, on the other side of the Andes, by indigenous peoples who live Argentinean territory, particularly the Mapuche and Ranquel.

In the third, more philosophical topic, Dr. Jovino Pizzi of the Universidad Católica de Pelotas, in his work "The faces of justice: a position. From the pragmaticphenomenological architectural", develops the new direction in ethics which introduces important changes in the conception of justice. The demands of application mean that, apart from the legal aspect, their applicability must also be guaranteed in various ambits: social, economic, cultural etc. However the model which we have at present follows liberal bases, as occurs with distributive justice in Brazil. Finally, Professor Juan Mansilla Sepúlveda of our University, in his "Ordo Amoris: the phenomenology of love in Max Scheler, order and disorder of the human heart", presents the Schelerian phenomenology of love taken from Augustine, leading to the conception of Ordo Amoris as the principal nucleus of the ethos of a man or a human collective: all social moral efforts are born of a fundamental love, and that love is in turn plural, directed towards many types of things, but ordered according to an order of their importance. It is, simply and solely, predilection. In essence, truths are founded from the order and disorder of the human heart.

With this new number, the Review takes another step forward in strengthening this

DOI: 10.7770/CUHSO-V16N2-ART287 
Revista CUHSO volumen $16 \mathrm{~N}^{\circ} 2$

meeting space between different disciplines and hopes to make a decisive contribution to the national and regional society in which it is inserted. By drawing attention to these philosophical, epistemological and methodological elements, we hope to find clues which will help us to understand the sociocultural transformations our time, and above all which will enable us to overcome

once and for all our hampering perspectives and practices, and open our minds to the new perspectives of the social sciences contextualized. 